\title{
Analysis and Strategy of Economic Development Policy for SMEs in Indonesia*
}

\author{
Dahliah DAHLIAH ${ }^{1}$, Agus KURNIAWAN² ${ }^{2}$ Aditya Halim Perdana Kusuma PUTRA ${ }^{3}$
}

Received: February 20, 2020 Revised: March 08, 2020 Accepted: April 03, 2020

\begin{abstract}
This study analyzes the strategy of determining economic development planning on SME improvement in Indonesia. A qualitative approach was conducted through interview questionnaires with twenty respondents, including sixteen Regional Apparatus Work Unit, Fisheries and Marine Office lecturers, subdistrict heads, and development observers. The method used is Analytical Hierarchy Process (AHP). AHP prioritizes criteria and sub-criteria to increase economic growth, reduce poverty, and increase community participation, while indicating the sub-criteria to optimize resource potential, strengthen micro-economy, develop tourism potential, utilize fishery potential and cultivation, and improve institutional performance. The AHP weighting results based on competitiveness and regional development of Bantaeng Regency is the priority in policy-making for a solution. The research shows that the government strategy, based on the perception of the stakeholders, is: optimizing resources strategy with priority to maximize the resource-carrying capacity that includes agriculture and farm, tourism development potential strategy, self-reliance of community groups and coaching and management. Strategies to strengthen micro economy include: industrial control, SMEs, community cooperatives and infrastructure improvements, strategies to improve institutional performance work capacity and work ethic, and strategies to utilize fisheries and cultivation potential technological development, provision of processed industries of fishery products, and improvement of the quality of the environment.
\end{abstract}

Keywords : Economics Development, SWOT, AHP

JEL Classification Code: A10, A12, B21, B16

\section{Introduction}

*Thanks to Simlitabdimas-UMI research funding, thanks also to co-authors, reviewers, and editors, as well as to the Rector, Dean of Faculty of Economics and Business and Research and Human Resource Development Institute (LP2S) of Universitas Muslim Indonesia - Makassar, Indonesia.

${ }_{1}^{1}$ First Author and Corresponding Author. Associate Professor, Department of Economics Development Studies, Faculty of Economics and Business, Universitas Muslim Indonesia, Makassar, Indonesia [Postal Address: Jalan Urip Sumohardjo KM.5, Makassar City, South Sulawesi, 90222, Indonesia], Email: dahliah.fekon79@gmail.com

${ }^{2}$ Assistant Professor of Department of Management, Universitas Puangrimaggalatung, Wajo, Indonesia

${ }^{3}$ Assistant Professor, Department of Management, Faculty of Economics and Business, Universitas Muslim Indonesia, Makassar, Indonesia [Postal Address: Jalan Tamalate 1 Tidung 4 Number 143, Makassar City, South Sulawesi, 90222, Indonesia] Email: adityatrojhan@gmail.com

(c) Copyright: The Author(s)

This is an Open Access article distributed under the terms of the Creative Commons Attribution Non-Commercial License (http://Creativecommons.org/licenses/by-nc/4.0/) which permits unrestricted noncommercial use, distribution, and reproduction in any medium, provided the original work is properly cited.
Regional autonomy gives the local government a great deal of authority to manage its affairs. The existence of the delegation of authority is contained in Law No. 23 of 2014 on the Regional Government. Through the legislation, it can be seen that regional autonomy has provided a new way in the process of local government by putting a high level of authority and responsibility in the hands of the local government (Sol, 2013; Meyer \& Meyer, 2016). This authority and responsibility are expected to provide high motivation in increasing the potential of the Bantaeng Regency of Indonesia. The provincial government of the Bantaeng Regency is asked to be more creative in managing and developing the region's potential to optimize development and economic growth. Therefore, development planning needs to be carried out appropriately with consideration of various aspects related to development problems in the area. Devising the development of the Bantaeng Regency must be following the direction and general policy of the provincial and national development plans, whereby every state institution is obliged to prepare such programs, including provinces and districts. The government still plays an essential role in the 
economy, in general, and development planning, in particular (Arnott, 2008; Meagher, 2013; Chen, 2007). In accordance with the mandate of the constitution, the government has an obligation to promote the general welfare, which means that the government is responsible for meeting the needs of every citizen through a system of government that supports the creation of excellent public services in order to meet the basic needs and civil rights of every citizen, such as public service goods, public services, and administrative services, enshrined in the General Explanation of Law Number 25 of 2004 on National Development Planning System.

The development of the region is an effort to spur socioeconomic development, reduce the gap between areas, and maintain environmental sustainability. Regional development policy is necessary because of the geographic, social, economic, and cultural conditions of different communities between regions, so that the implementation of the regional development policy must be adjusted to the terms, potentials, and issues of the problems in the area concerned (Farsani, Coelho, \& Costa, 2011; Faaij \& Domac, 2006). It further states that the process of regional development is influenced by internal as well as external factors, such as human migration, natural population growth, inherent resource potential, and investment and technology flows. So, it can be concluded that the purpose of regional development is: integrate the capability of each region in building an active national economic order; develop geographical competitive advantage through implementation of micro and macro policies and strategies; accelerate the development of strategic areas and rapid growth through particular systems, especially in increasing productivity and competitiveness; create a conducive climate in every region notably by supporting the development of business and investment; increase the capacity of human resources, both local government and local entrepreneurs, and the community; develop each region in order to have access to technological progress and innovation as well as to build the networking of global market.

This study analyzes factor pertinent to the development, of Bantaeng, and on this basis, formulate a strategy (Pienkhuntod, Amornbunchornvei, \& Nantharath, 2020; Meiyani \& Putra, 2019; Haming, Murdifin, Zulfikar Syaiful, \& Aditya, 2019; Akob, Arianty, \& Putra, 2020). The priority strategy policy considers potential abilities and constraints. While the priority of sub-criteria is to optimize resource potential, strengthen micro-economy, develop tourism potential, utilize fishery potential and cultivation, and improve institutional performance. The strategic priorities of the government are based on to the perception of the stakeholders. There is some urgency to conduct research (Hannum \& Buchmann, 2005) to address the main regional problems. Development rests on policy emphasis based on the specificity of the region concerned (endogenous development) by using the potential of human resources in Bantaeng District to create new job opportunities and stimulates economic growth. This is a problem identified by Long, Heilig, Li, and Zhang (2007). This orientation leads to taking initiatives in the development process originating from the area to create new job opportunities and economic stimulus (Flörke, Kynast, Bärlund, Eisner, Wimmer, \& Alcamo, 2013; Lalloo, Myburgh, \& Hobdell, 1999; Martinussen, 2015). Regional development as an effort to improve continually the quality and human life of Indonesian people and society, based on local capabilities by utilizing the progress of science and technology, and taking into account the challenges of regional, national, and global development. It further states that regional development, in general, includes: increasing economic conditions for self-reliance; increasing local social conditions for fair and equitable welfare provision; developing cultural diversity for sustainability; maintaining the security of the community in supporting the implementation of economic, social, cultural and environmental quality activities; and assisting the central government in maintaining the unity of the nation. The success of regional development is determined by several factors: regional conditions, covering the social, political, cultural, security, physical, and public facilities; a development plan, including objectives, development targets, strategies and development plans; the means of development, which includes the institutions, funds, human resources, and natural resources available; external influences, which include the social, political, economic, security conditions of the world, and the forces that specifically affect these; implementation, which includes the provisions, arrangements and implementation of the development plan.

'Strategy' derives from the Greek word stratiyeia, meaning, 'guiding,' 'moving,' and 'leading.' It can also be interpreted as the art of manipulating or employing, from the French word stratégie; the other meaning of the word strategy is 'strategies toward a goal.' Development Strategy (explicit strategy) is an action plan that explains the allocation of resources and various activities to face the environment, gain a competitive environment, transform the society, and achieve the goal (Slater \& Narver, 1994; Hakimi, 1983). In the context of successful development, not only is coordination required between agents and between levels of government, but there must also be coordination between the private sector and the public sector. The process of elaborating a development strategy plays a vital role in helping shape consensus, not only about the broader discourse about the country's future and short- and mediumterm goals, but also plays an essential part in achieving those goals. Consensus building is not only important as part of securing social and political stability, but also leads to the 'ownership' of policies and institutions that can increase success. A strategy should include components that aim to develop the private sector, the public sector, the community, the family, and the individual. 


\section{Literature Review}

The development of the domestic economy cannot be separated from events in global and regional economic conditions (Oktora \& Firdani, 2019). The interrelationship between trade relations, capital flows, and investments that occur at this time consists of several external factors that will affect the performance of the domestic economy. Based on this, the development of global and regional economic conditions needs attention as a consideration in the preparation strategies of national development. The years 2008 and 2009 were challenging for the global economy. The turmoil of the subprime mortgage crisis in the US in 2007 spread to financial markets in various countries. It finally brought a substantial impact on economic performance overall in these countries. The turmoil in the subprime mortgage market initially led to a decline in the value of assets of various global financial institutions and the collapse of capital markets and, then, to the bankruptcy of many companies in developed countries. These pressures eventually transformed into a crisis of employment and purchasing power, resulting in a weakening of the performance of the real sector and the overall economy.

Crisis pressure on the global economy was particularly visible from the second half of 2008 to the first semester of 2009. During this period, economies in various countries generally experienced a slowdown in growth rates even reaching negative growth. The worsening of these conditions can be seen from the financial performance of developed countries and, then, expanding to developing countries. Various policies to come out of the crisis have been implemented by countries, both collectively and individually. In this regard, the Government and monetary authorities in each state have adopted expansionary fiscal and monetary policies, which include increasing deficits and Government spending, decreasing interest rates, and liquidity assistance. Although it seems that these steps have produced relatively good results in the process of global economic recovery, the policies taken leave new challenges, especially for several countries in the European region.

The turmoil of the subprime mortgage crisis in the US also had an impact on the growing economies in European countries. In 2009, European economic growth for four consecutive quarters was in negative territory, so that overall growth in the European region reached minus 4.1 percent, down, when compared with the increase in 2008 of 0.6 percent. The economic contraction in the European region in 2009 was mainly due to negative growth in Germany, Britain, and France. In the first quarter of 2009, the economic growth of the three countries experienced a sharp decline - minus 6.7 percent, minus 5.5 percent and minus 3.9 percent, respectively. In the coming quarters, there was an economic improvement, although still in negative growth. Overall in 2009, the commercial growth rates of Germany, the United Kingdom, and France reached minus 4.9 percent, minus 4.9 percent, and minus 2.5 percent, respectively (see Appendix 1). Developed countries in the Asia-Pacific region felt economic pressures due to the global crisis that began in 2008 and 2009. In the first quarter of 2009, economic growth in Japan and South Korea fell to their lowest levels in the past two years, reaching minus 8.9 percent and minus 4.3 percent, respectively. Whereas the US and Canada experienced contractions with the lowest growth rates in the second quarter of 2009, reaching minus 4.1 percent and minus 3.8 percent, respectively (see Appendix 2).

External pressure, as a result of the global crisis, has affected the Indonesian economy in the period 2005-2009. During this period, the average Indonesian economy grew by 5.6 percent (YoY). In 2005, Indonesia's economy grew by 5.7 percent (YoY), which then slowed a little the following year to 5.5 percent (YoY). The economy again improved and experienced a reasonably high growth of 6.3 percent (YoY) in 2007. As a result of the global crisis that occurred in 2008, the Indonesian economy slowed to 6.0 percent (YoY). The slowdown continued until 2009 when the economy only grew by 4.5 percent (YoY) (see Appendix 3). In essence, economics is the science of recognizing the reality of scarcity and then thinking of ways to organize society toward the most efficient use of economic resources. This is where economics brings its unique contribution. The study of economics is carried out on two levels. First, the assessment is based on individual household and company decisions. It examines the interaction between individual households and companies in the market for certain goods and services. Second, it can be studied as a whole economic operation, which is a collection of all decisionmakers in all markets (Kireyeva \& Satybaldin, 2019).

\section{Research Methods}

\subsection{Location Quotient (LQ) Concept}

The analysis of the role of the sector in the improvement of economic growth can be identified by the inherent potential of a region. Regarding the acceleration and efficiency of regional development, it is necessary to determine the superior sectors that have comparative advantages and location specialization. Comparative advantage is the strength of a sector/commodity in a region relative to the sector/commodity in other areas (Miller, Gibson, \& Wright, 1991; Isserman, 1977). The ability of a part over a sector can be seen from the comparative advantages possessed by that particular sector within a region. This means that the industry can produce more than is needed by the region, so it has the potential to become an exporting area. By using the Location Quotient method, the ability of the sectors that become excellent in Bantaeng Regency of Indonesia can be utilized as a potential point (Billings \& Johnson, 2012). 


\subsection{SWOT Analysis and AHP}

The SWOT analysis discloses internal factors and external factors that are considered important in achieving the objectives, namely, by identifying strengths, weaknesses, opportunities, and threats (Jackson, Joshi, \& Erhardt, 2003). This analysis is based on the thinking that, in determining the policy strategy to be implemented, an organization must maximize its strengths and opportunities, while simultaneously minimizing existing weaknesses and threats to achieve a balance between internal conditions and external conditions. The SWOT analysis has several advantages: not only can it make future extrapolations, SWOT analysis can be used to create the future; be multipurpose and simple; matches other techniques, such as Delphi, Brainstorming, time series, regression (econometrics), and AHP; can be used to build consensus based on needs, and; desire. This method also combines the strengths of feelings and logic related to various issues, then synthesizes several considerations into outcomes that fit our expectations intuitively in view of as the factors that have been identified (Saaty, 2011; Golden, Wasil, \& Harker, 1989).

According to Saaty, there are three principles in solving the problem with AHP, namely, the principle of composing the hierarchy (Decomposition), the law of determining the priority (Comparative Judgment), and the policy of logical consistency (Logical Consistency). The authority in question is the hierarchy of problems to be solved in consideration of the criteria or components that support the achievement of the objectives. In the process of setting goals and objectives hierarchy, it should be noted whether the set of targets, along with the criteria, is appropriate for the problem at hand. In selecting the requirements on any decision-making problem, it is necessary to consider the following criteria: criteria must be completed to cover all the essential aspects, which are used in making decisions for the achievement of goals. Operations in the sense that each of these criteria must have meaning for the decision-maker, so that it can truly appreciate the alternatives, in addition to the means to help explain the tools with which to communicate. Criteria that contain the same meaning are to be avoided. Efforts are made to minimize the number of approaches to facilitate understanding of the problem and to simplify the problem in the analysis. Once the problem is defined, then it needs to be subjected to decomposition, namely, to break the whole issue into its elements. If you want to get accurate results, the solution requires going into the details of the earlier problem. For this reason, the analytical process is named hierarchy.

The making of the hierarchy does not require any specific guidance as to how many hierarchies are made, depending on the decision-maker who determines them by taking into account advantages and disadvantages. There are two types of hierarchy, namely, complete hierarchy, and incomplete hierarchy. In a complete hierarchy, all elements at all levels have all the elements present at the next level. Otherwise, it is called an incomplete hierarchy. This principle means assessing the relative importance of two elements at a certain level regarding the level above. This assessment is at the heart of the AHP, as it will affect the priorities of the elements. The result of this assessment is placed in a matrix form called a pairwise comparison matrix. In evaluating the comparable elements there are stages: which elements are more (important / liked / influential / others) and how often (important / liked / influential / other).

To obtain a useful scale when comparing the two elements, it is necessary to understand the general purpose: in the preparation of the range of interest, and when using a benchmark in the following table. In the relative importance assessment, two elements apply the reciprocal axioms, meaning that if the portion "I" is rated three times more critical than $j$, then the element $j$ must equal $1 / 3$ times the importance of the feature "I". Besides, the comparison of the same two elements will yield the number 1 , meaning it is equally important. Two different aspects can be judged similarly necessary. If the m-element is available, then the pairwise comparison matrix of " $\mathrm{M} x \mathrm{~N}$ will be obtained. The number of scores required in constructing this matrix is $n$ (n1) / 2 because the reciprocal pattern and its diagonal elements are equal to 1 . Synthesis of Priority From each pairwise comparison matrix, then searched the eigenvalue to get local priority. Because pairwise comparison matrices exist at each level, to obtain global priority synthesis must be done between domestic priorities. Sorting elements according to their relative importance through a synthesis procedure is called priority setting. Consistency has two meanings, the first is that similar objects can be grouped according to uniformity and relevance. The second is about the degree of relationship between objects based on specific criteria.

\section{Results and Discussion}

\subsection{Results}

The result of Location Quotient (LQ) analysis in the Bantaeng Regency sector that has the highest LQ value is from the agriculture, forestry, and fishery sector, with the cost of 1.56 in 2017, and 1.49 in 2018. This shows that in this sector to PDRB, about $34 \%$, so this sector is the base/seed sector of Bantaeng Regency. The main target that must be achieved by Bantaeng Regency is increasing the productivity and quality of food crops. Agricultural development, especially food crops, is directed to increase rice production, vegetables, and horticulture. Increased rice production is done through the program supported by the creation of new fields and adequate equipment. In general, the regional economy of the Bantaeng Regency of 
Indonesia is dominated by the agricultural sector, especially food crop agriculture, sub-sector of the plantation, livestock sub-sector, and fishery sub-sector. Appropriate processing criterium decisions software with the assessment of experts who represent three groups of stakeholders (see Table 1):

- Experts from the Central Government who are directly related to formulation and action, as well as knowing the results and observing the impact of budget policies and performance in Bantaeng District;

- Experts from local authorities or functional Bappaeda experts related to the jurisdiction of planning and implementation of specific strategies in the study area;

- Scholars or university experts who master policy issues in a global, national, and local development context and explore research methods and development theory based on superior local potential.

Table 1: SWOT Analysis

\begin{tabular}{|l|}
\hline Strength - Opportunity \\
\hline 1. Strengthening and Development of Resource Potential \\
of agriculture and plantation sector can increase \\
Regional Revenue (PAD) of Bantaeng Regency \\
2. Capacity Building and Performance of Local Institutions. \\
3. Socialization of regional potentials by utilizing \\
cooperation between the surrounding areas. \\
4. The geographical position of Bantaeng Regency \\
5. Availability of Basic Infrastructure \\
6. Facilities and infrastructure of the economy \\
7. Institutional capacity and performance \\
8. Potential of natural resources \\
9. Tourism potential \\
10. Efforts to disseminate the potential of the region \\
11. Determining the scale of development priorities \\
12. Bureaucratic system
\end{tabular}

\section{Strength - Threat}

1. Utilizing the strategic geographic condition as a trade center by improving infrastructure, economic infrastructure in Bantaeng Regency so that it can give advantages and capability to face globalization of free-market trade.

2. Improving the institutional and bureaucratic institutional performance capacity of the Bantaeng Regency Government, which regulates in facing economic, social, and political conditions so that it is necessary to provide local regulation that can contribute Bantaeng Regency.

3. Take advantage of the promotion of potential areas such as natural resources and tourism potential.

4. Managing central government funding support in allocating priority development to improve development in Bantaeng District.

\section{Weakness - Opportunity}

1. Improving road and economic infrastructure in areas with topographic conditions (highlands) in Bantaeng Regency to support the creation of economic activities and improve the quality of human resources.

2. Developing the potential of fishery and cultivation, especially on the possibility of seaweed that can be a superior product to increase the source of income Bantaeng regency.

3. Asserting the authority of drafting local regulations that pay attention to the distribution of development.

4. Policy on regional autonomy and central and local financial balance.

5. New Tax and Retribution Law Number 28 the Year 2009

6. New Law no. 20 The year 2008 concerning SME

7. Socio-political conditions in Bantaeng District

8. Central government programs

9. Central government support in the form of transfer

10. Advances in technology

11. Cooperation with areas around Bantaeng Regency.

12. Topographic conditions

13. Quality and quantity of human resources

14. Potential of fishery and cultivation

15. Working ethos, tenacity, and entrepreneurial spirit of society in the micro economy sector

16. Community participation level

17. The authority to draft legislation

18. Equitable regional development outcomes

19. Original local revenue and Regional Government Budget (APBD) structure.

\section{Weakness - Threat}

1. Improving the quality and quantity of human resources as well as work ethic and tenacity by growing the entrepreneurial spirit of the people of Bantaeng Regency in the face of globalization and free trade.

2. Increasing community participation in promoting agricultural products, plantations, and fisheries that can compete with other regions.

3. Conducting bureaucracy reform to align bureaucracy reform and law enforcement by the central government in improving and equitable development in Bantaeng Regency.

Based on the AHP results corresponding in the Hierarchy, the result of weight per sub-problem factor, when loads refer to the consideration of the problem are reviewed, the reference must be considered by policymakers as the basis of policy goals Weighted Criterion Factor Problem Structure Economics based on food, fishery and agriculture with low productivity. Utilization of the authorized capital that has been owned by the local government of the Bantaeng Regency to Maximize the Potential of Resources by 
developing the agricultural and plantation sector in Bantaeng Regency needs a farming container to manage and place sales in determining commodity prices.

Table 2 shows developing tourism potential owned by the local government of Bantaeng Regency, and making Bantaeng Regency tourism area. In addition to having good tourism potential, as well as attractive social and political condition, Bantaeng Regency can be developed into a tourist destination, so as to increase Original Revenue Regional (PAD). Promoting work ethic, tenacity, and the entrepreneurial spirit of society in the microeconomic sector to further strengthen the economy through small industries, SMEs, and cooperatives, will prepare for free competition. Improving the capacity, work ethic, and performance of institutions and employees within the local government of Bantaeng District, and increasing community participation in the planning, implementation, and supervision of regional development will maximize the implementation of regional autonomy, and increase PAD through new Taxes and Levies. The Potential Fisheries and Cultivation owned by Bantaeng Regency can be utilized by maximizing the growing technology to produce superior quality fishery products, and set up cooperation with other areas around Bantaeng Regency.

Table 2: Development Policy Strategy of Bantaeng Regency of Indonesia

\begin{tabular}{|l|c|c|}
\hline \multicolumn{1}{|c|}{ Weight in Priorities } & Goal Level & Priority \\
\hline Increasing Resource Potential & 0.483 & 1 \\
\hline Developing Tourism Potential & 0.208 & 2 \\
\hline $\begin{array}{l}\text { Strengthening the Micro } \\
\text { Economy }\end{array}$ & 0.199 & 3 \\
\hline $\begin{array}{l}\text { Improving Institution } \\
\text { Performance }\end{array}$ & 0.072 & 4 \\
\hline $\begin{array}{l}\text { Utilizing the Potential of } \\
\text { Fisheries and Cultivation }\end{array}$ & 0.036 & 5 \\
\hline
\end{tabular}

Based on the above comparison, it can be concluded that the hierarchy created to find the priority order of the development policy of the Bantaeng Regency is reasonably unstable. This is understandable because planning the development of the region is strongly influenced by many factors, not just internal factors of local government, but also external factors that cannot be controlled, such as national or international conditions. This means that if there is a significant change, it will also change the development goals as well as the policy priorities. By understanding the instability of the hierarchy in determining the priorities of this regional development policy, local governments can anticipate if something unexpected happens.

\subsection{Discussion}

The results of the analysis show that local economic competitiveness and development in Bantaeng District seeking to lift institutions and communities from poverty other than through public management capacity and community empowerment has not been fully effective. Business groups such as farmers and fishermen who became the motor of local economic programs ought to involve poor families in commodity development activities. Based on the findings of the 2007 Bappenas research results, most of the local and central government have not optimally involved the entrepreneurs, farmer groups, and low-income families in a holistic way to play a proactive role in achieving the target of developing the local economy. Improving economic competitiveness should be done through:

a. Development of superior regional commodities (agribusiness, marine fisheries, marine, and cultural tourism) that are competitive both nationally and globally.

b. Business protection with clear legal certainty, including prioritizing local wisdom that supports the creative economy for the Bantaeng Regency community.

c. Empowerment of SME and rural communities of farmers and fishermen with potential entrepreneurs, including the strengthening of cooperative institutions.

As regards the strategy of Regional Development Policy to Reduce Poverty in Bantaeng Regency, the reduction of poverty, according to the respondents' assessment, is a strategy that should be prioritized by Bantaeng District Government. In this case, this strategy calls on Bantaeng District Government to utilize the necessary capital controlled by the local government of Bantaeng Regency, to optimize the potential of natural resources (agriculture, plantation and fishery) as the superior sector with favorable geographical condition. It can be used as current economic growth support and necessary available facilities and infrastructure capable of supporting the economy to maximize the implementation of the Regional Autonomy law and the law on the financial balance between the central and regional governments, as well as the Regional Tax and Retribution Law, in order to increase the Original Income Regional (PAD) and Regional Development of Bantaeng Regency.

\section{Conclusions}

Bantaeng Regency has three superior sectors in the agriculture sector, namely, the food crop sector, plantation, and fishery sector, because the LQ value is more significant than one. The agricultural industry has the highest LQ value 
in 2014 of 1.56 and by 2015 at 1.49 , which means 34.0 percent contributes to agrarian productivity of Bantaeng Regency. Judging from the Development of Competitive Development Policy and Realization of Regional Development program, Bantaeng Regency Government developed a policy of acceleration of regional development based on the real potency as follows: Economic Structure based on Food, Fishery and Agriculture with Low Productivity; Development of Tourism Potential, which has a lot of impact on the economy of Bantaeng Regency; Strengthening the economy through small industries, SMEs, and cooperatives; and Improve work capacity, work ethic, and agency performance. The policy is utilizing the Potential of Fishery and Cultivation owned by the Bantaeng Regency. The above policy is a solution to overcome the strategic issues that arise in supporting the optimal development of regional development, which include: support of the local government in improving agriculture, plantation, and fishery; formulate policy applying Farm Size Expansion system where every family of farmers is given ownership of a farm to manage; control of the price of products produced by farmers; provide of a proper processing place so that the product can be maximized; regulation in zoning, agricultural layout, plantation and fishery, and; development of technology that can improve the productivity of farms, estate, and fisheries. The policy can increase the original revenue of the regional revenue, and the welfare of society can be achieved.

The AHP weighting results for the achievement of the Policy Development Objectives based on Competitiveness and Regional Development of Bantaeng Regency is the priority in policy-making for a solution. The main problems reviewed are related to Food-based, Fisheries, and Agriculture Structures with Low Productivity as the biggest problem in Bantaeng Regency, which does not yet involve human resources. Based on the results of the planning and implementation of programs by the Center and related areas, as mentioned above, the objectives and targets can be achieved if the following is done: Local Government of Bantaeng Regency makes it a development priority by paying more attention to the potential of resources that exist there, because this can trigger economic growth and make a considerable contribution to the structure of the economy; to turn the leading sectors as a source of local revenue; to cultivate the potential of government resources Bantaeng Regency can establish a processing industry based on SMEs in agriculture, fishery and plantation in view of Bantaeng Regency's considerable potential; improve the various infrastructures that support the agriculture, fisheries, and plantation sectors (such as technology applications and processing industries) and the tourism sector, if the Bantaeng Regency Government wishes to make these sectors the economic leading sectors.

\section{References}

Akob, M., Arianty, R., \& Putra, A. H. P. K. (2020). The Mediating Role of Distribution Kahn's Engagement: An Empirical Evidence of Salesforce in Indonesia. Journal of Asian Finance, Economics and Business, 7(2), 249-260. https://doi. org/10.13106/jafeb.2020.vol7.no2.249

Arnott, R. (2008). Housing policy in developing countries: The importance of the informal economy (pp. 167-191). Washington, DC: World Bank. https://doi.org/10.1596/978-0-8213-7573-0

Billings, S. B., \& Johnson, E. B. (2012). The location quotient as an estimator of industrial concentration. Regional Science and Urban Economics, 42(4), 642-647. https://doi.org/10.1016/j. regsciurbeco.2012.03.003

Chen, M. A. (2007). Rethinking the informal economy: Linkages with the formal economy and the formal regulatory environment (DESA Working Papers No. 46). New York, NY: United Nations, Department of Economics and Social Affairs.

Faaij, A. P. C., \& Domac, J. (2006). Emerging international bio-energy markets and opportunities for socio-economic development. Energy for Sustainable Development, 10(1), 7-19. https://doi.org/10.1016/S0973-0826(08)60503-7

Farsani, N. T., Coelho, C., \& Costa, C. (2011). Geotourism and geoparks as novel strategies for socio-economic development in rural areas. International Journal of Tourism Research, 13(1), 68-81. https://doi.org/10.1002/jtr.800

Flörke, M., Kynast, E., Bärlund, I., Eisner, S., Wimmer, F., \& Alcamo, J. (2013). Domestic and industrial water uses of the past 60 years as a mirror of socio-economic development: A global simulation study. Global Environmental Change, 23(1), 144-156. https://doi.org/10.1016/j.gloenvcha.2012.10.018

Golden, B. L., Wasil, E. A., \& Harker, P. T. (1989). The analytic hierarchy process. Applications and Studies (1st Ed., pp. 1-256). Berlin, Germany: Springer. https://doi.org/10.1007/978-3-64250244-6

Hakimi, S. L. (1983). On locating new facilities in a competitive environment. European Journal of Operational Research, 12(1), 29-35. https://doi.org/10.1016/0377-2217(83)90180-7

Haming, M., Murdifin, I., Zulfikar Syaiful, A., \& Aditya, H. P. K. P. (2019). The Application of SERVQUAL Distribution in Measuring Customer Satisfaction of Retails Company. Journal of Distribution Science, 17(2), 25. https://doi.org/10.15722/ jds.17.02.201902.25

Hannum, E., \& Buchmann, C. (2005). Global educational expansion and socio-economic development: An assessment of findings from the social sciences. World Development, 33(3), 333-354. https://doi.org/10.1016/j.worlddev.2004.10.001

Isserman, A. M. (1977). The location quotient approach to estimating regional economic impacts. Journal of the American Institute of Planners, 43(1), 33-41. https://doi. org/10.1080/01944367708977758

Jackson, S. E., Joshi, A., \& Erhardt, N. L. (2003). Recent research on team and organizational diversity: SWOT analysis and 
implications. Journal of Management, 29(6), 801-830. https:// doi.org/10.1016/S0149-2063_03_00080-1

Kireyeva, A. A., \& Satybaldin, A. A. (2019). Analysis of Gender Pay Gap in Different Sectors of the Economy in Kazakhstan. Journal of Asian Finance, Economics and Business, 6(2), 231238. https://doi.org/10.13106/jafeb.2019.vol6.no2.231

Lalloo, R., Myburgh, N. G., \& Hobdell, M. H. (1999). Dental caries, socio-economic development and national oral health policies. International Dental Journal, 49(4), 196-202. https:// doi.org/10.1111/j.1875-595X.1999.tb00522.x

Long, H., Heilig, G. K., Li, X., \& Zhang, M. (2007). Socioeconomic development and land-use change: Analysis of rural housing land transition in the Transect of the Yangtse River, China. Land Use Policy, 24(1), 141-153. https://doi. org/10.1016/j.landusepol.2005.11.003

Martinussen, J. (2015). Society, state and market: A guide to competing theories of development. Cape Town, South Africa: HSRC Press. ISBN: 978-07969-1795-9. 1-400.

Meagher, K. (2013). Unlocking the informal economy: A literature review on linkages between formal and informal economies in developing countries. ISBN 978-92-95095-56-4

Meiyani, E., \& Putra, A. H. P. K. (2019). The relationship between Islamic leadership on employee engagement distribution in FMCG industry: Anthropology business review. Journal of Distribution Science, 17(5), 19-28. https://doi.org/10.15722/ jds.17.5.201905.19

Meyer, N., \& Meyer, D. F. (2016). The relationship between the creation of an enabling environment and economic development: A comparative analysis of management at local government sphere. Polish Journal of Management Studies, 14(2), 150-160. https://doi.org/10.17512/pjms.2016.14.2.14
Miller, M. M., Gibson, L. J., \& Wright, N. G. (1991). Location quotient: A basic tool for economic development analysis. Economic Development Review, 9(2), 40-65.

Murdifin, I., Pelu, F., M. A., Halim Perdana Kusuma Putra, A., Muara Arumbarkah, A., Rahmah, A., Muslim Indonesia, U., \& Rahmah, A. (2019). Environmental disclosure as corporate social responsibility: Evidence from the biggest nickel mining in Indonesia. International Journal of Energy Economics and Policy, 9(1). https://doi.org/10.32479/ijeep.7048

Oktora, S. I., \& Firdani, A. M. (2019). Natural Rubber Economics between China and Southeast Asia: The Impact of China's Economic Slowdown. Journal of Asian Finance, Economics and Business, 6(2), 55-62. https://doi.org/10.13106/jafeb.2019. vol6.no2.55

Pienkhuntod, A., Amornbunchornvei, C., \& Nantharath, P. (2020). Quantitative Analysis of Poverty Indicators: The Case of Khon Kaen Province, Thailand. Journal of Asian Finance, Economics and Business, 7(2), 131-141. https://doi.org/10.13106/ jafeb.2020.vol7.no2.131

Saaty, T. L. (2011). What is the Analytic Hierarchy Process? In Mathematical Models for Decision Support. Berlin, Germany: Springer. eISBN: 978-3-642-83555-1 https://doi. org/10.1007/978-3-642-83555-1_5

Slater, S. F., \& Narver, J. C. (1994). Does competitive environment moderate the market orientation-performance relationship? Journal of Marketing, 58(1), 46-55. https://doi. org/10.2307/1252250

Sol, D. A. (2013). The institutional, economic and social determinants of local government transparency. Journal of Economic Policy Reform, 16(1), 90-107. https://doi.org/10.108 $0 / 17487870.2012 .759422$ 